\title{
Marking Their Own Homework: The Pragmatic and Moral Legitimacy of Industry Self-Regulation
}

\author{
Frances Bowen ${ }^{1}$
}

Received: 4 October 2016/ Accepted: 3 July 2017/Published online: 8 August 2017

(c) The Author(s) 2017. This article is an open access publication

\begin{abstract}
When is industry self-regulation (ISR) a legitimate form of governance? In principle, ISR can serve the interests of participating companies, regulators and other stakeholders. However, in practice, empirical evidence shows that ISR schemes often under-perform, leading to criticism that such schemes are tantamount to firms marking their own homework. In response, this paper explains how current management theory on ISR has failed to separate the pragmatic legitimacy of ISR based on selfinterested calculations, from moral legitimacy based on normative approval. The paper traces three families of management theory on ISR and uses these to map the pragmatic and moral legitimacy of ISR schemes. It identifies tensions between the pragmatic and moral legitimacy of ISR schemes, which the current ISR literature does not address, and draws implications for the future theory and practice of ISR.
\end{abstract}

Keywords Corporate social responsibility - Governance · Industry self-regulation · Regulation · Legitimacy

Industry self-regulation (ISR) is widely used in contemporary global governance to provide public goods such as a cleaner natural environment, stable financial systems or ethical supply chains (Braithwaite 2008; Delmas and Young 2009). Defined as the voluntary association of firms to control their collective behaviour (King and Lenox 2000), ISR schemes have been used to regulate issues from food labelling to privacy, from living wages to

Frances Bowen

f.bowen@qmul.ac.uk

1 School of Business and Management, Queen Mary University of London, Mile End Road, London E1 4NS, UK environmental accounting standards, and from pollution to Internet pornography. Proponents have argued that ISR can achieve public policy objectives at lower cost than government regulation because regulatory decisions are made by those with the best information and expertise to make them (Coglianese and Mendelson 2010; Gunningham and Rees 1997). ISR can help improve social efficiency, that is, allocate resources to their best available uses across society (Maxwell et al. 2000). ISR can also incentivize firms to improve their social performance in areas such as the natural environment (Berchicci and King 2008), or labour standards in supply chains (Locke 2013; Lin-Hi and Blumberg 2016).

Despite theoretical and practical enthusiasm for ISR, questions remain about its legitimacy. Mounting empirical evidence suggests that all too often industry-led schemes do not lead to positive social benefits or fix the problems that they are designed to solve (King et al. 2012). Recent scandals on mislabelled horsemeat in food supply chains, privacy in the self-regulated newspaper industry, and the fatal collapse of the BSCI-certified Rana Plaza factory in Bangladesh have fed popular scepticism that ISR is tantamount to firms "marking their own homework". However, as many teachers know, when done well, asking students to mark their own homework can not only be efficient from the teacher's point of view, but also encourage students to learn from each other and to reflect on their own performance. Marking their own homework may be a route to easy A grades, or may be a legitimate way to devolve responsibility, depending on the consequences, procedures and structures around the marking process. Current ISR theory cannot yet tell the difference.

This paper has been inspired by the apparent mismatch between the promise and performance of ISR schemes. It maps what we know about the legitimacy of ISR schemes 
from management theory, shows where previous research from different traditions has focused, and uses this to explore blind spots, tensions and future directions on the legitimacy of ISR. Explaining how and why the evaluation of ISR schemes differs so much between theorists is a vital step towards improving the performance of ISR schemes in practice. Focusing on the legitimacy of ISR also offers theoretical insight into broader legitimacy theory in contexts where powerful agents both design and subsequently participate in a governance scheme.

Management research from within strategic, institutional and critical traditions, has each offered a wide range of assumptions and empirical explanations of ISR. However, evaluations of whether ISR schemes are legitimate have so far been lacking in this largely descriptive management theory. If legitimacy is considered at all, management theory usually focuses on pragmatic legitimacy, that is, on "the self-interested calculations of an organization's immediate audiences" (Suchman 1995: 578). Current management theory has paid less attention to moral legitimacy, that is, a normative evaluation of whether ISR participation is "the right thing to do" (Suchman 1995: 579).

This paper builds on Suchman's (1995) framework and separates the pragmatic legitimacy of ISR based on selfinterested calculations, from moral legitimacy based on normative approval. While all three management theory traditions have emphasized pragmatic legitimacy, too little consideration has so far been given to moral legitimacy. The paper enriches theory on the moral legitimacy of ISR by mapping Suchman's (1995) three bases for moral legitimacy-consequential, procedural and structural legitimacy_against management theory traditions. Mapping debates in this way is useful because previous studies within each of the management traditions have tended to implicitly assume which aspect of moral legitimacy is most important based on the worldview of the analyst, rather than the details of the empirical context. This paper draws all three theoretical strands together for the first time and provides a springboard to examine tensions and blind spots on the legitimacy of ISR. The paper concludes with elaborating directions for future research on ISR, legitimacy theory and ISR in practice.

\section{Management Theories of Industry Self-Regulation}

Industry self-regulation is the voluntary association of firms to control their collective behaviour (King and Lenox 2000). ISR is "a regulatory process whereby an industrylevel, as opposed to a governmental- or firm-level, organization... sets and enforces rules and standards relating to the conduct of firms in the industry" (Gupta and Lad 1983:
417). Management scholars have theorized ISR participation from three main perspectives: strategic, institutional and critical perspectives, each of which is briefly introduced in this section. The different perspectives illustrate how various theorists have understood ISR schemes, which has implications for whether and how the schemes are seen as successful and legitimate.

\section{Strategic Management Perspectives}

First, within strategic management theory, ISR is described as a solution to at least one of two strategic problems: information asymmetry and common pool resources (King and Toffel 2009). Outsiders are unable to directly observe a firm's social performance. Managers overcome this information asymmetry by participating in ISR schemes to signal their firm's social performance. ISR schemes in industries such as toy manufacturing (Lin-Hi and Blumberg 2016), cut flowers (Prado 2013), sustainable agriculture (Blackman and Rivera 2011) or coffee (Reinecke et al. 2012) enable firms to signal their social or environmental quality. Common pool resources, on the other hand, require firms to collaborate to protect a shared resource such as the industry's reputation, access to physical assets or supply chain resilience (Prakash and Potoski 2006; Barnett and King 2008). Strategic perspectives emphasize that ISR schemes are often led by dominant firms that have the greatest interest in addressing the problem as with Nike or Walmart's leadership in collective efforts to eliminate sweatshop labour from supply chains (O'Rourke 2003; Locke et al. 2007).

\section{Institutional Perspectives}

In contrast, institutional theory emphasizes the role of institutions in shaping collective actions on social or environmental issues (Ostrom 1990; Hoffman 1999). Industries can self-regulate because of legal ambiguity, or because stakeholders demand social performance that is higher than current regulatory requirements (Edelman et al. 1991; Gunningham and Rees 1997). For example, Zietsma and Lawrence's (2010) study of the evolution of decisions on harvesting practices in the British Columbia forest industry showed how managers actively participated in creating, maintaining and disrupting industry collective actions. ISR can also co-evolve with other institutions. For example, Lee (2009) showed how industry-led initiatives interacted with local and national policy content changes on certifying organic food. Institutional perspectives explain ISR as a way for managers to maintain conformance with regulative, cognitive and normative requirements in the institutional environment (Hoffman 1999; Matten and Moon 2008). 


\section{Critical Management Perspectives}

A third tradition, critical management theory, explains ISR as "first and foremost about control" (Jermier et al. 2006, p. 627). Critical theorists focus on the discourses around proposed solutions to social problems, and the roles that these discourses play in protecting corporate privilege and power (Banerjee 2008). Managers use ISR to maintain control over the rhetoric around social issues through generating and maintaining symbols such as certifications, logos, social reports and partnerships. Boiral (2013), for example, theorized sustainability reports certified to the Global Reporting Initiative (GRI) A or A+ standard as "signs and images employed to control social representations" (p. 1037). Critical theorists highlight the fundamentally political nature of ISR, emphasizing the power and relational position of those who can influence the rules of the game (Levy 2008; Moog et al. 2015). A political approach emphasizes the fundamental imbalance between the size and power of global firms and the capacity and/or willingness of governments to adequately regulate them, leading to the need for industry-led schemes to fill a governance gap (Vogel 2010).

\section{The Legitimacy of Industry Self-Regulation}

Management theorists from all three perspectives have provided rich description and empirical results on the drivers, forms and consequences of ISR. However, amid accusations that firms and managers are marking their own homework, more research attention is required on the legitimacy of ISR schemes. Legitimacy is a "generalized perception or assumption that the actions of an entity are desirable, proper, or appropriate within some socially constructed system of norms, values, beliefs and definitions" (Suchman 1995: 574). Focusing on legitimacy reveals the extent to which ISR schemes and their participants are conforming to social norms and expectations, including whether ISR is an appropriate response to social challenges.

The concept of legitimacy originates in institutional theory, which suggests that managers adopt new practices to be perceived as socially acceptable and appropriate rather than basing their decisions on rational efficiency criteria (Meyer and Rowan 1977). However, both strategic and critical management theory also use variants of legitimacy. Strategic management theory tends to emphasize the extent to which the approval of various stakeholder groups influences firms' social strategy (e.g. Darnall et al. 2009; Kassinis and Vafeas 2006). In contrast, the critical approach delves more deeply into the processes by which firms seek and earn legitimacy through their social disclosures and actions (e.g. Crane 2000; Fineman and Clarke 1996).

Numerous typologies of legitimacy have been proposed in the literature (see Bitektine 2011 for a review), but the most widely used is Suchman's (1995) distinction between pragmatic and moral legitimacy. Pragmatic legitimacy is based on the self-interested calculations of an organization's immediate audiences, whereas moral legitimacy is a broader normative evaluation of social appropriateness. Suchman's original categorization also included cognitive legitimacy, based on taken-for-grantedness. However, cognitive legitimacy is less useful in evaluating ISR because of the lack of stable and shared assumptions about industry's role in governance (Baur and Palazzo 2011). Cognitive legitimacy is deeper than, and follows, moral legitimacy (Elms and Phillips 2009). Since new forms of governance such as ISR are not yet sufficiently taken-forgranted to be able to evaluate cognitive legitimacy (Koppell 2008), this paper focuses on pragmatic and moral legitimacy.

Others have applied Suchman's distinction between pragmatic and moral legitimacy in related contexts such as implementing codes of ethics (Long and Driscoll 2008), social enterprise (Dart 2004), NGOs as partners of industry (Baur and Palazzo 2011), or of regulatory regimes (Black 2008). Some prior studies have also examined whether particular ISR schemes have pragmatic and moral legitimacy, as in the case of Schepers' (2010) and Cashore's (2002) evaluations of the Forest Stewardship Council. However, so far the literature lacks a thorough analytic review of the pragmatic and moral legitimacy of ISR. Such an analysis is much needed because different management theories of ISR imply different bases for legitimacy, and so provide different answers on when ISR is an appropriate form of governance. The next section reviews the pragmatic legitimacy of ISR from each management theory tradition to provide a foundation for further analysis.

\section{The Pragmatic Legitimacy of Industry Self- Regulation}

Pragmatic legitimacy is based on self-interested calculations of an organization's most immediate audiences. It is an exchange-related form of legitimacy based on an organization's capacity to persuade key stakeholders of its usefulness (Elms and Phillips 2009). An analytic review of ISR research reveals four core benefits to firms and their immediate stakeholders from ISR: to maintain strategic control, to gain reputation, to leverage networks and to learn how to address social issues. This section will demonstrate how these benefits are discussed in all three families of management theory. While each theoretical 
Table 1 Pragmatic legitimacy of industry self-regulation

\begin{tabular}{|c|c|c|c|c|}
\hline $\begin{array}{l}\text { Private } \\
\text { benefits }\end{array}$ & Description & Strategic perspective & Institutional perspective & Critical perspective \\
\hline $\begin{array}{r}\text { Strategic } \\
\text { control }\end{array}$ & $\begin{array}{l}\text { Maintain the ability to respond to social issues } \\
\text { on the firm's own terms }\end{array}$ & $\begin{array}{l}\text { Meeting stakeholder } \\
\text { expectations flexibly } \\
\text { and at lower cost } \\
\text { (Majumdar and } \\
\text { Marcus 2001; } \\
\text { Coglianese and Nash } \\
\text { 2001) }\end{array}$ & $\begin{array}{l}\text { Maintaining agency to } \\
\text { respond to institutional } \\
\text { pressures } \\
\text { (Gunningham and Rees } \\
\text { 1997; Hoffman 1999; } \\
\text { Zietsma and Lawrence } \\
\text { 2010) }\end{array}$ & $\begin{array}{l}\text { Exerting control over } \\
\text { rhetoric and } \\
\text { resources } \\
\text { (Raynolds et al. 2007; } \\
\text { Gereffi et al. 2001; } \\
\text { Moog et al. 2015) }\end{array}$ \\
\hline Reputation & $\begin{array}{l}\text { Position firm to gain positive social evaluations } \\
\text { from other stakeholders for social } \\
\text { performance }\end{array}$ & $\begin{array}{l}\text { Signalling quality or } \\
\text { behaviour } \\
\text { (King et al. 2005; } \\
\text { Aravind and } \\
\text { Christmann 2011) }\end{array}$ & $\begin{array}{l}\text { Meeting stakeholder } \\
\text { expectations } \\
\text { (Jiang and Bansal 2003; } \\
\text { Boiral 2007) }\end{array}$ & $\begin{array}{l}\text { Demonstrating prestige } \\
\text { and status } \\
\text { (Fuller and Tian 2006; } \\
\text { Boiral 2013) }\end{array}$ \\
\hline $\begin{array}{l}\text { Network } \\
\text { benefits }\end{array}$ & $\begin{array}{l}\text { Advantages increase with the number or esteem } \\
\text { of members in an ISR scheme }\end{array}$ & $\begin{array}{l}\text { Reputation commons } \\
\text { and club theory } \\
\text { (Barnett and King } \\
\text { 2008; Prakash and } \\
\text { Potoski 2006) }\end{array}$ & $\begin{array}{l}\text { Institutions shape collective } \\
\text { actions } \\
\text { (Ostrom 1990; Delmas and } \\
\text { Montes-Sancho 2010) }\end{array}$ & $\begin{array}{l}\text { Authority of high- } \\
\text { status actors to set } \\
\text { norms } \\
\text { (Levy and Egan 2003; } \\
\text { Renard 2005) }\end{array}$ \\
\hline Learning & $\begin{array}{l}\text { Learn how to cope with social concerns where } \\
\text { there is uncertainty about social issues firms } \\
\text { face and how to deal with them }\end{array}$ & $\begin{array}{l}\text { Learning as a } \\
\text { competitively } \\
\text { valuable capability } \\
\text { (Locke 2013) }\end{array}$ & $\begin{array}{l}\text { Mimetic isomorphism and } \\
\text { shared norms } \\
\text { (Braithwaite 2008; Matten } \\
\text { and Moon 2008; Haack } \\
\text { et al. 2012) }\end{array}$ & $\begin{array}{l}\text { Diffusing shared } \\
\text { rhetoric } \\
\text { (Green 2004; } \\
\text { Christensen et al. } \\
\text { 2013) }\end{array}$ \\
\hline
\end{tabular}

Works cited are illustrative only. Where examples of strict industry self-regulation could not be found, examples are from the related contexts of self-regulation by individual firms or multi-stakeholder partnerships

perspective differs in the relative importance placed on each of these exchange-based benefits, each view accepts that ISR schemes may be granted pragmatic legitimacy by key stakeholders for a variety of reasons (see Table 1).

\section{Strategic Control}

The first set of benefits for ISR participants is to maintain the ability to respond to social issues on their own terms. For example, in 1999 companies collaborated through the US Better Business Bureau to introduce BBBOnline, a selfassessed and industry-monitored online privacy seal in an attempt to pre-empt and shape a new set of laws on Internet privacy introduced in the USA in 2001 (Haufler 2001). Strategic management theory explains that firms may use ISR to strategically pre-empt costly sanctions or requirements from governments, NGOs, consumer groups or other stakeholders (Majumdar and Marcus 2001; Fleckinger and Glachant 2011). Institutional theories describe ISR as a strategic response to institutional pressures, where managers try to retain agency within the constraints of actual or potential regulatory control (Oliver 1991; Hoffman 1999; Wijen 2014). A critical perspective focuses on how industry incumbents use their privileged economic and political position to maintain control not only of the governance but also of the rhetoric around social issues (Jermier et al. 2006). Bartley (2005), for example, showed how the US apparel industry succeeded in replacing a discourse of legal compliance with one based on compliance to voluntary industry codes in response to rising stakeholder concerns about sweatshop labour. This enabled firms to maintain control over compliance through participating in the Fair Labor Association (FLA) to certify labour standards. Thus, all three management theories recognize ISR as a way for firms to retain strategic control over aligning their own interests with other stakeholders, which is crucial for gaining pragmatic legitimacy.

\section{Reputation}

Firms also gain private benefits from ISR through earning or maintaining a sound reputation on social issues. Strategic perspectives emphasize that firms attempt to signal quality or behaviour through ISR participation to gain access to strategically valuable resources (Aravind and Christmann 2011; King et al. 2005). Institutional perspectives focus on the extent to which firms are seen to be behaving according to stakeholder expectations (Jiang and Bansal 2003; Delmas and Toffel 2008). Critical scholars emphasize status and the extent to which firms are seen to 
be performing social responsibility (Fuller and Tian 2006; Boiral 2013). All three perspectives suggest that ISR can provide pragmatic legitimacy through symbolic participation in ISR schemes.

\section{Network Benefits}

Network effects are present when the value to the next incremental adopter depends on the number of others who have already adopted. Evidence on ecolabels for green buildings, forestry and the apparel industry suggests that the higher the rate of adoption, the more an ISR scheme is recognized as a credible signal of environmental quality, and the higher the benefit of adoption to the next incremental adopter (Bartley 2003; Chan et al. 2009). ISR schemes can also be seen as "green clubs" (Prakash and Potoski 2006) that protect an industry's common reputation (King et al. 2002). These schemes can help develop the collective reputation, resources, staff, networks and expertise that lower the cost to individual firms of participation and are particularly successful in "small worlds" such as forestry (Conroy 2007) or the Chinese toy manufacturing industry (Lin-Hi and Blumberg 2016) where all the major players know each other. Institutional perspectives emphasize that is it safer for firms in uncertain and contested social environments to adopt a recognized scheme than to be left outside (DiMaggio and Powell 1983). The higher the ratio of certified to non-certified firms in a local ISR scheme, the more likely are new entrants to participate to signal their similarity (Husted et al. 2016). A more critical perspective asks how ISR regimes gain the authority to govern particular social issues (Cashore 2002), highlighting the importance of high-status political actors in encouraging others to participate (Levy and Egan 2003). As Renard (2005) demonstrated in the context of fair trade labelling, networks can be vital to encouraging widespread participation in an ISR scheme, but can also further embed existing power structures within an industry. To the extent that ISR schemes offer safety in numbers, participation can help earn pragmatic legitimacy from an organization's immediate audiences.

\section{Learning}

Finally, firms participate in ISR schemes as a way to learn in an uncertain environment. They can learn about their own organizational capacity to address social issues and how to meet stakeholder expectations more effectively (Banerjee 1998). Participation in a scheme can facilitate the transfer of best practices and increase communication and information sharing between members through direct contact (Kraatz 1998; King and Lenox 2000). Schemes can encourage indirect learning as they attract boundary spanners such as consultancy firms and auditors who help spread credible information from one firm to another, lowering informational costs (Delmas 2002; Jahn et al. 2005). Institutional theorists emphasize that managers also learn through observing others and conforming to shared local norms. ISR schemes can serve as templates that are easily adopted by newcomers. Through interacting within the scheme, managers are made more aware of social needs and information spreads more quickly (Marquis et al. 2007). Focusing on the rhetoric of ISR, critical theorists also ask how managers learn to talk about social issues and solutions (Green 2004). Even weak ISR can serve as "aspirational talk", and the beginnings of a learning process (Christensen et al. 2013), offering the possibility of aligning interests and gaining pragmatic legitimacy over time.

\section{Private Benefits and Pragmatic Legitimacy of ISR}

ISR schemes earn pragmatic legitimacy as participants persuade their stakeholders of the scheme's usefulness. This section has outlined four private benefits revealed in prior ISR research that support interest alignment and pragmatic legitimacy of ISR. Although different management theory perspectives have analysed ISR based on widely divergent assumptions, each has touched upon the core private benefits of strategic control, reputation, network benefits and learning. Analysts in the strategic management tradition have tended to approach the benefits of participation from a narrow, enlightened self-interest perspective, and so have most clearly articulated the private benefits of ISR. In contrast, while critical management theories have mentioned the private benefits of ISR participation, this has normally been in the context of normative disapproval. ISR participation may secure control over rhetoric and resources (Raynolds et al. 2007; Gereffi et al. 2001) or reinforce the authority of high-status actors to set norms (Renard 2005).

However, while ISR schemes may offer private benefits and pragmatic legitimacy from the organization's most proximate audiences, schemes may still not be in the overall public interest (Vogel 2008). Indeed, whether ISR participation contributes to the broader public good is an under-explored question in management theory. Pragmatic legitimacy alone is not an adequate basis for evaluating legitimacy since it only takes account of transactional interest alignment with immediate audiences. Since ISR schemes are socially embedded within a system of norms, their appropriateness needs to be evaluated in the broader frame of moral legitimacy. The next section develops this by applying Suchman's (1995) typology of moral legitimacy to the ISR context to evaluate the moral legitimacy of ISR schemes. 


\section{The Moral Legitimacy of Industry Self-Regulation}

Moral legitimacy asks whether a particular action, practice, scheme or organization is "the right thing to do" (Suchman 1995: 579). It differs fundamentally from pragmatic legitimacy because it focuses on the ethical foundations of an organization or activity (Melé and Armengou 2015), and the reciprocal responsibility norms generated between an organization and its stakeholders (Elms and Phillips 2009). Assessing moral legitimacy requires looking beyond pragmatic evaluations based on interest alignment, to a broader public perspective on the normative appropriateness of ISR. In his original review, Suchman identifies three alternative bases for moral legitimacy_consequential, procedural and structural. Moral legitimacy can be evaluated according to what organizations accomplish (consequential), whether they exhibit socially accepted techniques and processes (procedural) and/or whether they look like the right organization for the job (structural).

Previous management research has tended not to focus on the moral legitimacy of ISR. This has led to an overly private and transactional approach to evaluating ISR schemes. In response, this section draws together past ISR research and outlines how ISR schemes have been evaluated according to each of Suchman's bases for moral legitimacy. It shows how each management theory perspective has tended to emphasize different bases of moral legitimacy (Table 2), and why this matters for evaluating ISR.

\section{Consequential Legitimacy}

Consequential legitimacy focuses on the outcomes of ISR. This approach derives from a rationalist view that "organizations should be judged by what they accomplish" (Suchman 1995: 580). Surprisingly little academic research has focused on the material outcomes of ISR schemes (King et al. 2012), and existing evidence on the outcomes of ISR schemes is mixed at best. Famous examples of ISR schemes that are generally assumed to improve participating firms' social or environmental performance over time include the chemical industry's Responsible Care Program (King and Lenox 2000), the Equator Principles for responsible project finance (Haack et al. 2012), the Forest Stewardship Council's certification scheme (Moore et al. 2012) and ISO 14001 (Prakash and Potoski 2006). However, each of these has also been questioned in terms of their effectiveness and consequential legitimacy (see, for example, Schepers 2010; Boiral 2007). Empirical studies show that the environmental performance of participating firms in the US chemical industry's Responsible Care, the ISO 14001 standard and sustainable agriculture certification is no better and in some cases is worse than that of non-participants (Russo and Harrison 2005; Blackman and Rivera 2011; Gamper-Rabindran and Finger 2013).

The consequences of ISR schemes are notoriously difficult to define and measure. Indeed, one of the problems in evaluating ISR effectiveness is the different ideologically driven perspectives on ISR effectiveness from whose perspective, over what time period and as compared to what

Table 2 Moral legitimacy of industry self-regulation

\begin{tabular}{|c|c|c|c|}
\hline & Strategic perspective & Institutional perspective & Critical perspective \\
\hline $\begin{array}{l}\text { Consequential } \\
\text { legitimacy }\end{array}$ & $\begin{array}{l}\text { Firm-level outcomes } \\
\text { Short-term, direct, measurable effects } \\
\text { (Rivera 2002; Blackman and Rivera 2011) }\end{array}$ & $\begin{array}{l}\text { Field-level outcomes } \\
\text { Short-term behaviour change; longer- } \\
\text { term field reconfiguration } \\
\text { (Hoffman 1999; Haack et al. 2012) }\end{array}$ & $\begin{array}{l}\text { Social, symbolic and } \\
\text { material outcomes } \\
\text { Long-term and diffuse } \\
\text { effects } \\
\text { (Boiral 2013; Christensen } \\
\text { et al. 2013) }\end{array}$ \\
\hline $\begin{array}{l}\text { Procedural } \\
\text { legitimacy }\end{array}$ & $\begin{array}{l}\text { Credible performance signal } \\
\text { Monitoring and sanctions for non-compliance } \\
\text { (Lenox and Nash 2003; Darnall and Carmin 2005; } \\
\quad \text { Aravind \& Christmann 2011) }\end{array}$ & $\begin{array}{l}\text { Stakeholder disclosure and scrutiny, } \\
\text { including regulators } \\
\text { Codification of norms } \\
\text { Interpretive flexibility } \\
\text { (Wijen 2014; Terlaak 2007; Short and } \\
\text { Toffel 2010) }\end{array}$ & $\begin{array}{l}\text { Ambition of performance } \\
\text { levels } \\
\text { Transparency and } \\
\text { accountability } \\
\text { Relationship to state } \\
\text { (Moog et al. 2015; Renard } \\
\text { 2005) }\end{array}$ \\
\hline $\begin{array}{l}\text { Structural } \\
\text { legitimacy }\end{array}$ & $\begin{array}{l}\text { Fit with competitive and regulatory context } \\
\text { (Prado 2013; Rivera 2002) }\end{array}$ & $\begin{array}{l}\text { Demonstrates socially } \\
\text { acceptable values and norms } \\
\text { Consistent with regulatory demands } \\
\text { within field } \\
\text { (Locke, Rissing and Pal 2013; Lee } \\
\text { 2009) }\end{array}$ & $\begin{array}{l}\text { Authoritative emblems } \\
\text { and discourses } \\
\text { Nested within governance } \\
\text { networks } \\
\text { (Cashore 2002; Gilbert } \\
\text { and Rasche 2007) }\end{array}$ \\
\hline
\end{tabular}


(Gupta and Lad 1983). Past studies have assessed the consequences of ISR schemes by examining the extent to which schemes fulfil the functional or governance functions they were designed to serve (Hahn and Pinkse 2014; Wijen 2014), whether they encourage participation (Prado and Woodside 2015; Schuler and Christmann 2011), whether they trigger pro-social behaviour change in participating firms (Terlaak 2007; Schuler and Christmann 2011), whether they improve allocative efficiency (Maxwell et al. 2000; Fleckinger and Glachant 2011) and ultimately whether they deliver material improvements in the social domains they are designed to address (Blackman and Rivera 2011; Darnall and Sides 2008; Aravind and Christmann 2011).

Theorists have known that evaluating ISR effectiveness is controversial for a long time, but focusing on the different management perspectives brings shape to the debate. Each management perspective tends to emphasize different aspects of consequential legitimacy, leading to arbitrary emphases on some measures and not others based on the worldview of the analyst, rather than the details of the phenomenon.

Strategic perspectives on ISR tend to evaluate the consequences of ISR by firm-level outcomes (see Table 2). This includes whether participation in ISR schemes generates private benefits to the firm such as the ability to charge higher prices (Rivera 2002), or improves firm-level social or environmental performance (Blackman and Rivera 2011). Given the focus on the firm level, strategic perspectives tend to emphasize short-term, direct and measurable effects of ISR participation. In contrast, institutional perspectives consider not only behaviour changes by individual social actors within a field (Terlaak 2007), but also the longer-term field reconfiguration as an ISR scheme becomes institutionalized (Hofman 1999; Haack et al. 2012). Critical perspectives examine longer-term and diffuse effects of ISR schemes, including how ISR alters symbolic representations of reality (Boiral 2013) and the overall governance within a policy domain (Renard 2005). Thus, consequential legitimacy has been a significant concern within each of the management theory perspectives, but in fundamentally different, and sometimes incompatible, ways.

\section{Procedural Legitimacy}

Since it is so difficult to evaluate the consequences of ISR, for whom and when, an alternative is to instead rely on evaluating the design of the schemes. Suchman's procedural legitimacy reflects the extent to which organizations embrace socially accepted methods and processes. In the absence of unambiguous evidence that an ISR scheme has positive outcomes, firms instead demonstrate "sound practices [which] may serve to demonstrate that the organization is making a good-faith effort to achieve valued, albeit invisible, ends" (Suchman 1995: 580). In the case of ISR, the procedural legitimacy of the scheme's methods and processes is usually demonstrated through stringency of ISR design. Schemes with strong monitoring, third-party auditing, government involvement and highly codified processes are usually assumed to provide the most procedural legitimacy (Delmas and Terlaak 2001; Christmann and Taylor 2006; Darnall and Sides 2008; Short and Toffel 2010). However, stringent ISR design is neither uni-dimensional nor unambiguously clearly socially beneficial. ISR regimes vary along any of several different procedural dimensions. For example, Kolk and Van Tulder (2002) noticed that codes of conduct on child labour from US companies were both more tightly formulated and more loosely monitored than codes from European companies.

Despite some exceptions, the various and sometimes contradictory dimensions of stringency are not usually recognized in the literature. This has led to ISR theorists from different traditions focusing on different aspects of stringency, and to talking past each other. Different management theory traditions tend to emphasize different dimensions of procedural legitimacy and downplay others, regardless of whether this is the most salient in any given circumstance. Strategic perspectives usually prioritize monitoring and sanctions as a way to limit information asymmetry and free-riding (Lenox and Nash 2003; Darnall and Carmin 2005). In contrast, institutional perspectives emphasize codification and the flexibility provided by ambiguous norms in self-regulation (Edelman 1992; Wijen 2014), or interactions with the broader institutional context (Gunningham and Rees 1997; Lee 2009; Short and Toffel 2010). Critical perspectives often question the ambition or transparency of ISR schemes (Cashore 2002; Gilbert and Rasche 2007; Moog et al. 2015) and the potential for ISR to pre-empt stricter government regulation through altering power relations and diminishing the role of the state ( $\mathrm{Re}$ nard 2005; Jermier et al. 2006). Thus, each tradition has a distinctive, but usually implicit view on which aspects of procedural legitimacy are most useful in evaluating the moral legitimacy of ISR schemes, with no one tradition addressing all aspects of procedural legitimacy.

\section{Structural Legitimacy}

Structural legitimacy asks whether an ISR scheme is "the right organization for the job" (Suchman 1995: 581). Structural legitimacy is less about consequences and procedural actions, and more about the structural appearance of an ISR scheme and its place within the broader governance system. Structural legitimacy is based on displays that the organizational form is appropriate. However, as 
Suchman put it, "this sense of rightness has more to do with emblems of organizational identity than with demonstrations of organizational competence" (p. 581).

Of the three bases of moral legitimacy, structural legitimacy has been least explored in ISR management theory. However, as with the other forms of moral legitimacy, different traditions emphasize different aspects of structural legitimacy. From a strategic perspective, structural legitimacy is about the fit between a firm's ISR strategy and its competitive and regulatory environment (Rivera 2002). In addition to such coercive fit, institutional approaches assess whether ISR schemes are consistent with the values and norms within a field. Credentials such as ISO certificates can serve as "organizational degrees" (Boiral 2012), or useful objects to signal credibility (Delmas and Montes-Sancho 2011). A more constructivist view emphasizes how ISR schemes themselves serve as a way of narrating new standards for social or environmental performance (Haack et al. 2012). Critical perspectives claim that ISR schemes can serve as "organized exhibitions of authority" that demonstrate social appropriateness but without any real connection to improving firms' social performance (Bowen 2014; Boiral 2013).

\section{Management Theories of ISR and Moral Legitimacy}

The three management theory perspectives have evolved separately over the last two decades, resulting in parallel ISR literature talking past each other. Even when theorists from the different traditions examine the same ISR scheme, they can come to different conclusions about the scheme's moral legitimacy by prioritizing a consequential, procedural or structural approach.

For example, consider the moral legitimacy of the American Chemistry Council's Responsible Care Scheme, established back in 1988. Taking a strategic perspective, Gamper-Rabindran and Finger (2013) evaluated the consequential legitimacy of the Responsible Care scheme by focusing on the environmental performance outcomes of participating compared with non-participating firms. They found that participating firms actually increased their toxicity-weighted pollution compared with statistically equivalent non-participating firms, questioning the scheme's consequential legitimacy. Gunningham's (1995) institutional perspective focused on Responsible Care's codes of practice and community engagement processes as adopted in Australia, arguing based on procedural legitimacy that it is "the most significant and far-reaching selfregulatory scheme ever adopted in Australia, or arguably, elsewhere" (p. 61). In contrast, critical perspectives emphasize symbolic importance of Responsible Care as a response to the 1984 disaster that killed some 2500 people at the Union Carbide subsidiary in Bhopal, India (Gereffi et al. 2001). The chemical industry needed to take steps to regain public acceptance after Bhopal, and "a code of conduct, a certificate, even literally a 'symbol', was necessary to communicate those steps" (Matten 2003: 224). Critical theorists explain this as an attempt by the chemical industry to maintain the structural legitimacy of the prevailing regulatory system and Responsible Care within it.

Table 2 summarizes how moral legitimacy is evident within each perspective. Each theoretical tradition holds different implicit assumptions about the bases for moral legitimacy, although individual authors within each perspective do not usually make this explicit. Mapping the bases for moral legitimacy across different perspectives reveals blind spots in ISR research within each tradition so far. For example, within the strategic management perspective with its focus on the comparative analysis of different outcomes in different circumstances, there has been inadequate attention to evaluating the long-term, indirect and social consequences of ISR schemes (King et al. 2012). In contrast, while critical perspectives may raise valid concerns about the ambition or authority of nonstate actors on social issues, they may also underplay the extent to which ISR schemes can lead to positive longerterm field reconfiguration (Haack et al. 2012).

\section{Tensions Between Pragmatic and Moral Legitimacy}

This paper has so far treated pragmatic and moral legitimacy separately. However, the pragmatic legitimacy that can provide the basis for a social licence to operate is not the same as the more stable moral legitimacy based on ethical principles (Melé and Armengou 2015) and reciprocal responsibility (Elms and Phillips 2009). Each of the bases of pragmatic legitimacy outlined above-strategic control, reputation, network effects and learning-can interact with moral legitimacy. This section identifies tensions between pragmatic and moral legitimacy, and the management theory perspectives in which the tensions are based. This is useful to identify blind spots and to generate routes forward for future theory and practical evaluations of ISR.

\section{Strategic Control and Moral Legitimacy}

Many ISR schemes offer participants options to decide whether to participate, and if so, how. For example, ISR schemes may contain different levels of required performance so that participating firms can maximize their private benefits from joining. Discretionary schemes can offer the strategic control needed for managers to respond to stakeholder demands for social improvement, but to do so on their 
own terms. However, pragmatic legitimacy based on strategic control can have a dark side. The strategic goal of ISR participation can be to limit the need to change behaviour, either in advance of regulation or later when the industry's preferred approach may be subsequently adopted as a new regulatory standard (Ogus 1995; Fleckinger and Glachant 2011). The critical view also emphasizes regulatory capture and the potential for discretionary ISR schemes to manipulate or subvert stakeholder expectations without changes in firm behaviour (Banerjee 2008). Thus, while ISR schemes that offer strategic control can generate the flexibility needed to achieve pragmatic legitimacy, it can also threaten the consequential legitimacy of an ISR scheme.

Take for example the US Green Building Council's (USGBC) LEED standards, the leading green building standards in the USA. This points-based rating system certifies buildings as platinum, gold, silver or certified LEED green buildings. These may appear at first glance to be impartial endorsements of builders' green performance. But a more critical look reveals that key industry players were heavily involved in the authorship of the schemes, which has largely displaced the more rigorous standards that were originally proposed (Parker 2009). The USGBC is often mistaken to be a government agency, but was originally a coalition of builders, consultants and property developers who realized that they needed to respond to stakeholder demands for greener buildings. They designed a flexible scheme that offered firms control over which technologies to implement to earn a green building label and therefore meet the pragmatic legitimacy expectations of their immediate stakeholders. This flexibility encouraged builders to strategically target the cheapest and least environmentally impactful building features, or to target the lowest acceptable tier of LEED certification, which offers very little material improvement to the environment from the building (Corbett and Muthulingam 2007).

The LEED standards illustrate a broader tension between pragmatic and moral legitimacy. ISR schemes can help participants maintain strategic control, but in order for this to be effective, participants' interests must somehow dominate those of other stakeholders. Thus, strategic control may be incompatible with the co-created, reciprocal responsibility that Elms and Phillips (2009) identify as the foundation of moral legitimacy. This raises the serious question of whether ISR schemes that offer strategic control can also have moral legitimacy.

\section{Reputation and Moral Legitimacy}

Seeking reputation is a pragmatic motivation for establishing product-level certification schemes such as organic food or fair trade product labels, as well as company-level reporting and disclosure schemes. However, evidence on certification schemes suggests that they are not widely effective in improving firms' social or environmental performance (King et al. 2012). This lack of effectiveness is at least partly because ISR schemes designed to confer reputation often emphasize persuasion to confer pragmatic legitimacy rather than the co-creation of norms and actions required for moral responsibility.

The institutional perspective explains how managers may get caught up in larger structural pressures that require them to implement, measure, monitor and report on social performance (Bromley and Powell 2012). Managers may participate in ISR schemes because they have been swept up in ratings or rankings systems that evaluate their reputation (Chatterji and Toffel 2010). Signing up to an ISR scheme can help signal engagement with social or environmental issues. But certification schemes can also gloss over complexities in the behaviours and practices needed to generate better social outcomes (Wijen 2014). ISR schemes that provide reputation and pragmatic interest alignment can hide considerable ambiguity on how the scheme is put into practice and whether it is the right organization for the job.

Consider the example of CarbonNeutral ${ }^{\circledR}$ certification. Achieving certification is intended to help firms stand out from their competition and provide a "clear sign" that they are leading the way on climate change (Carbon Neutral Company 2016), that is, to offer pragmatic reputational benefits. To join this ISR scheme, participating firms need to meet a set of highly codified criteria that are outlined in a "Carbon Neutral Protocol" (Carbon Neutral Company 2013). Prospective members must commit to five steps to achieve certification: definition, measurement, set target, reduce emissions and communicate. Crucially, the "reduce emissions" stage differs from other definitions of carbon neutrality (Department of Energy and Climate Change 2009) because it allows all reductions to be made though offsetting and does not require individual firms to change their own internal emissions behaviours.

Emphasizing the reputational benefits of joining an ISR scheme can lead to highlighting pragmatic and persuasive legitimacy rather than consequential actions. Microsoft explained its adoption of the CarbonNeutral ${ }^{\circledR}$ certificate because it found that it could not meet its previous 2009 commitment to reduce relative carbon emissions by $30 \%$ by 2012. Microsoft's new cloud computing business model was driving gross carbon emissions up, so in order to protect its environmental reputation the firm opted for the pragmatic legitimacy of achieving certification rather than the consequential legitimacy of actually reducing its own internal emissions (Microsoft 2012). Certification schemes such as this illustrate the tension in ISR between the pragmatic legitimacy gained through persuasion and the moral legitimacy of consequential changes in behaviours and performance. 


\section{Network Effects and Moral Legitimacy}

Some ISR schemes offer economies in membership, or collective shelter from institutional pressures by following the example of dominant firms in the field. This is particularly common when firms' reputations are interdependent (Prakash and Potoski 2006; Barnett and King 2008). On the plus side, ISR schemes designed to harness pragmatic legitimacy through network effects can lead to positive spillover and multiply positive impacts. For example, Reich et al. (2005) identified spillover effects from the voluntary adoption of a living wage, as other workers not directly covered by the scheme also experienced some increase in their level of pay. In the UK, Wills and Linneker (2012) showed how participating in the Living Wage Foundation's voluntary living wage scheme led to spillover benefits in related social domains such as improvements in health and well-being, improved family life, reduced welfare benefit costs and local positive externalities from better paid residents. ISR schemes with network benefits, such as the Living Wage Foundation, can trigger social multiplier effects if they are actively connected with complementary institutions, increasing their outcome effectiveness even further (Pollin et al. 2002; Freeman 2005). Extensive cross-monitoring and dialogue can lead to networked legitimacy, where the ISR scheme draws together a nexus of interests and each participant gains its own pragmatic legitimacy (Mele and Schepers 2013).

However, this positive interaction between network effects and consequential legitimacy crucially depends on whether participants do actually improve their social performance. Critical theorists describe how network effects can support shared discourses and industry-led schemes that consolidate the power of large corporations without altering corporate behaviour (Banerjee 2008; Bowen 2014). Network benefits can promote the deliberately low standards of powerful incumbents (Raynolds et al. 2007). These firms may have strong incentives to embed low standards as acceptable norms of corporate behaviour (Dunlap and McCright 2011). Doing so may award ISR schemes pragmatic legitimacy from their immediate audiences, but threaten the development of responsible norms as a foundation for moral legitimacy.

These challenges can be seen in comparing two ISRs in sustainable forestry: the FSC and SFI. Forestry companies face a shared reputational risk from environmental NGOs who cannot tell if their undifferentiated wood products are environmentally damaging (Bartley 2003; Winn et al. 2008). Both the FSC and SFI are voluntary ISR programmes that were initiated at the industry level: by the US forestry industry in the case of SFI, and by socially concerned retailers in the case of FSC (Cashore 2002). In the early days of sustainable forestry certification, the US forestry industry actively resisted the FSC's more ambitious standards, preferring instead to start their own lighter touch, SFI scheme in order to attract more participants (Coglianese and Nash 2001; Meidinger 2006). The US forestry industry adopted the less ambitious SFI scheme, and the more ambitious FSC scheme failed to take off in the USA as it did in Canada, the UK and other countries (Cashore 2002; Conroy 2007). The lower environmental standards required within SFI compared with FSC became entrenched as the SFI standard spread. Worse, because forestry certification is interlinked with other schemes, such as for green buildings, this consequential legitimacy loss spilled over into other US industries when the USGBC controversially decided to award LEED points for using SFI-certified wood in their buildings.

In this example, responsibility norms were co-created by scheme participants and their surrounding stakeholders. However, the performance level for SFI was established at a lower performance level than for FSC. More generally, the moral legitimacy of ISR schemes with potent network effects crucially depends on the ethical foundations of the emerging shared norms (Melé and Armengou 2015). Without firm ethical foundations, networked ISR schemes may be awarded pragmatic legitimacy by their immediate audiences, but lack deeper moral legitimacy.

\section{Learning and Moral Legitimacy}

ISR schemes vary in their potential scope for learning opportunities and the extent to which these learning exchanges are actually realized (Coglianese and Nash 2001). ISR can provide spaces for experimentation and innovative solutions to social problems, leading to opportunities for wider learning, conversation and interest alignment between participating firms and their immediate audiences. ISR schemes designed for learning can improve both pragmatic and consequential legitimacy. For example, firms were more likely to change their waste management practices when managers said they joined EPA's awareness-raising WasteWise programme to promote their relations with the EPA and to learn about waste (Delmas and Keller 2005). Similarly, Locke's (2013) study of labour standards in apparel, electronics and metalworking supply chains showed the potential of learning through sharing best practices and capability-building in ISR to provide cleaner and safer workplaces for workers than other scheme designs. ISR on labour standards in global supply chains has helped managers incorporate and learn from the voices of traditionally excluded groups of workers such as women export workers (Pearson and Seyfang 2001) and has also stimulated learning among activists about what worked in affecting change in previous campaigns (Freeman 2005). 
However, as with network effects, the consequential legitimacy of ISR schemes designed for learning depends on what is learned and shared within the scheme. Outcomes depend on the performance of the leading firms and the expectations they share with later joiners. The primary motivation to participate may be to learn how to avoid, deflect or pre-empt more ambitious regulatory requirements (Ogus 1995), or to co-opt or deflect stakeholder interests (Parker 2002; Raynolds et al. 2007). All four of the ISR schemes examined by Lenox and Nash (2003) in the chemical, textile and pulp and paper industries were designed with sharing mechanisms such as industry newsletters, annual conferences and member meetings. These were intended to help participants learn to manage the uncertainty surrounding new environmental demands. However, in most of the schemes, the performance bar was not sufficiently ambitious to offer learning to new members on reducing pollution. Similarly, Lin-Hi and Blumberg (2016) emphasized the learning potential from schemes such as the Business Social Compliance Initiative (BSCI), which focuses on learning and capacity building to improve working conditions in global supply chains. However, two of the factories in the Rana Plaza building in Bangladesh that collapsed in 2013 were participants in the BSCI. Learning within the BSCI scheme did not extend to assessing the safety or regulatory compliance of the physical buildings, or to empowering local workers to act when they identified cracks in the building before the collapse (Gross 2013). Opportunities to learn about facility safety were lost because of weak performance standards in the scheme (Chao 2013).

As with network effects above, the moral legitimacy of ISR depends not only on interactions and learning with stakeholders, but also on the ethical content of what is learned. Moral legitimacy requires the learning to have firm ethical foundations (Melé and Armengou 2015). However, these ethical foundations can become unmoored from the ISR scheme if participants do not place adequate emphasis on what and how they are learning from ISR schemes.

\section{Tensions and Implications}

This section addressed each of the bases of pragmatic legitimacy in turn and used past ISR research from all three management theory perspectives to explore potential tensions with moral legitimacy. Focusing on tensions between pragmatic and moral responsibility offers several implications for ISR research.

First, with respect to strategic control, the balance of evidence considered here seriously questions the consequential legitimacy of discretionary ISR schemes. Rather like students marking their own homework, it is tempting for managers to award themselves the easy points but without truly engaging with fundamental changes in their activities. This is even the case in performance-based ISR schemes such as the USGBC's LEED building standards. Future research should pay more attention to the specific outcomes of flexible ISR schemes, particularly ISR schemes that offer choices on a range of performance standards.

Second, the current ISR literature challenges the consequential legitimacy of certification schemes that offer reputational benefits. Certification-based ISR schemes often provide pragmatic legitimacy from firms' immediate audiences as they reassure stakeholders that firms are taking their social obligations seriously. Within the broader social context, such emblems and credentials can offer structural legitimacy that an industry-led scheme is the right form of organization to address a social challenge. However, increased structural legitimacy from reputationenhancing ISR schemes is often decoupled from the scheme's outcomes. Thus, future research should further investigate the structural conditions of ISR schemes and their outcomes.

Finally, for ISR schemes that offer network and learning effects, the pragmatic reasons to participate can multiply the positive outcomes of an ISR scheme. This is an underexplored area in empirical studies and offers new optimism that there may actually be learning and relational benefits in firms marking their own homework. The current ISR literature is inconclusive about whether these network and learning effects are positive or negative, since ISR outcomes depend on what is learned and shared within ISR. More research is needed on formally modelling learning effects and network spillover in ISR. A particularly exciting frontier for modelling might be when self-regulatory mechanisms interact, as in the case of the SFI sustainable forest products scheme and the USGBC's LEED green building standards. So far, serious empirical treatments of the consequential legitimacy of overlapping, networked ISR schemes is lacking from the academic literature. The wide range of ISR schemes now operating provides an opportunity for future empirical research to explore these ideas both within and across industry sectors.

\section{Summary and Conclusions}

In principle, ISR can provide flexible and innovative social improvements at lower cost than direct state regulation (Coglianese and Mendelson 2010; Gunningham and Rees 1997). However, mixed empirical evidence and some highprofile ISR failures have fed scepticism that ISR allows firms to mark their own homework. Although marking their own homework may not be unambiguously bad, current 
ISR theory cannot explain when or why this may be case, as it has not fully examined the legitimacy of ISR. While legitimacy theory clearly separates the pragmatic legitimacy of gaining a social licence to operate from a deeper, more stable moral legitimacy (Suchman 1995; Melé and Armengou 2015), ISR research has been slow to recognize this distinction. In response, this paper mapped what we know about the legitimacy of ISR from management theory, clearly separated pragmatic from moral legitimacy, and used this distinction to expose tensions and future directions on the legitimacy of ISR.

\section{Theoretical Implications}

This paper offers extensions to three strands within ISR theory. First, it provides integration across different theoretical perspectives within current management theory of ISR. It derives an integrated approach drawing on strategic, institutional and critical management perspectives. Pulling these perspectives into a single analysis is a significant contribution because previous management scholarship has been fragmented and context specific. Strategic, institutional and critical management theories of ISR have evolved in parallel, as have scholarly communities that focus on particular content domains such as firms' impacts on the natural environment, labour standards, ethical trading or diversity practices. This paper leverages and integrates across these parallel studies and offers the broader view needed to explore the biases, blind spots and boundary conditions of ISR.

Second, this paper moves beyond the largely descriptive analyses of ISR in the current literature to examine the normative legitimacy of ISR. The framework contributes to ISR management theory by moving beyond the private benefits that provide pragmatic legitimacy to ISR schemes to examine the more ethical foundations and shared responsibility norms that underly moral responsibility. The framework derived in Table 2 can guide a comprehensive evaluation of moral legitimacy based on the details of a particular ISR scheme, rather than implicitly assuming which aspect of moral legitimacy is most important as has been so common in management theories of ISR. Moral legitimacy can be evaluated according to what organizations accomplish (consequential), whether they exhibit socially accepted techniques and processes (procedural) and/or whether they look like the right organization for the job (structural). Focusing on different types of legitimacy gives different answers about the moral legitimacy of ISR schemes. Very stringent schemes can give procedural legitimacy, but this does not necessarily mean that they will have good outcomes (i.e. consequential legitimacy). Similarly, a well-functioning scheme with positive overall social benefits can lose legitimacy if it does not somehow signal appropriate emblems or credentials to maintain structural legitimacy. Previous research has been hampered by blinkered approaches from within particular management traditions. This paper offers an integrative view of moral legitimacy of ISR based on the different bases of moral legitimacy, rather than the implied theoretical worldview of the analyst.

Finally, the paper contributes to a burgeoning literature on the pragmatic and moral legitimacy of other phenomena such as codes of ethics (Long and Driscoll 2008), social enterprise (Dart 2004), NGOs as partners of industry (Baur and Palazzo 2011), regulatory regimes (Black 2008) or controversial projects (Melé and Armengou 2015). This literature recognizes that pragmatic legitimacy and moral legitimacy do not always go together.

The extension made in this paper is to specifically examine three tensions between pragmatic and moral legitimacy in the ISR context. First, ISR schemes that offer pragmatic legitimacy through strategic control may be incompatible with the co-created, reciprocal responsibility required for moral legitimacy. Participants in ISR schemes cannot simultaneously dominate and responsibly reciprocate with stakeholders, leading to serious questions about whether ISR schemes that offer strategic control can also have moral legitimacy. Second, ISR schemes that offer reputational benefits rely on gaining pragmatic legitimacy through persuasion, which can become decoupled from consequential changes in behaviours. Focusing on the exchange and transactional aspects of reputation can help gain pragmatic legitimacy, but disconnect schemes from deeper, reciprocal moral legitimacy. Third, the moral legitimacy of ISR schemes with potent network or learning effects crucially depends on the ethical foundations of the scheme. Ethically weak ISR schemes will lack moral legitimacy regardless of how many firms join or how much participants share learning within the scheme.

Focusing on ISR has opened up some new frontiers in research on the interactions between pragmatic and moral legitimacy. ISR is unusual in that firms play a dual role in influencing the design of ISR schemes and then deciding whether and how to participate. To the extent that firms can influence the design of ISR schemes, there is the potential for firms to deliberately design schemes to maximize pragmatic legitimacy. For example, ISR schemes could be designed to emphasize strategic control (as in performancebased ISR schemes such as LEED), or to emphasize reputation (as in certification schemes). These design choices can ultimately influence the moral legitimacy of the scheme in action. It is possible that the tensions between pragmatic and moral legitimacy identified in this paper are a consequence of this dual role in ISR. This analysis challenges legitimacy theorists to assess whether these tensions between pragmatic and moral legitimacy are 
unique to circumstances where organizations both design and participate in governance schemes or are generalizable to other contexts beyond ISR.

\section{Practical Implications}

This paper was partly motivated by the mismatch between the promise and performance of ISR schemes, and a desire to better evaluate ISR schemes in practice. Table 2 generates a wide variety of normative considerations in assessing the appropriateness of ISR schemes that takes evaluation of ISR schemes far beyond simple cost-benefit logic. Scheme participants and stakeholders can use Table 2 to generate a systematic set of questions to evaluate the legitimacy of specific ISR schemes. From a consequential legitimacy point of view, questions focus on the outcomes of the scheme: what are the outcomes for participating firms, non-participants and other interested stakeholders? What are the direct and indirect outcomes over the short and long term? Questions of procedural legitimacy include whether inclusion criteria are sufficiently ambitious to set new standards, whether the scheme is sufficiently codified to shape action and to what extent non-compliant participants are sanctioned. Structural legitimacy questions ask about the extent to which the authority of the ISR scheme is formally recognized within the relevant country or industry, whether the ISR scheme reflects acceptable values for its social context and whether and how the form of the ISR conveys that firms are performing their proper social function. Systematic questions beyond simple short-term cost-benefit analysis have the potential to identify and develop relatively more socially beneficial ISR schemes in the future, and ultimately to improve ISR schemes in practice.

\section{Limitations}

The primary limitation of this analysis is that it is based on an analytic review of past research from a sprawling range of traditions and substantive policy domains. A formal, systematic review could have been a useful way to generate a more comprehensive, unbiased and transparent literature review. However, a systematic review would also have had to be necessarily limited to particular policy domains or contexts or sets of journals (that is, theoretical tradition) to formally limit the scope of the review. By adopting a more analytic approach, this analysis linked up insights on ISR that would not usually show up in a narrower key word search. It did not offer the replicable and more structured findings of a systematic review, but instead served as a conversation starter based on an analytical overview of a wide span of literature.
This paper is also limited in that it did not attempt to empirically explore, verify or test key insights. Future research on the structural conditions of ISR schemes and their outcomes is particularly needed, and is now increasingly possible because of the very large number of schemes that could be compared. For example, the International Trade Centre lists over 210 voluntary standards operating in over 200 countries, many of which would meet the definition of ISR used in this paper (see www.standardsmap.org). Similarly, www.ecolabelindex.com lists over 450 ecolabels across 25 industry sectors. Empirical researchers might collate existing evidence on the effectiveness of these standards or ecolabels and develop preliminary tests and categorizations on which ones have the most learning or network potential, and how they rank on the various dimensions of consequential, procedural or structural legitimacy. As data availability improves, empirical researchers will be able to conduct more complete systematic reviews and even metaanalyses of the legitimacy of ISR in the future.

\section{Conclusion}

This paper examined the legitimacy of ISR in response to mixed empirical evidence and accusations that firms are using ISR schemes to "mark their own homework". It explained how current management theory on ISR has failed to separate pragmatic legitimacy of ISR schemes based on private benefits, from moral legitimacy based on reciprocal responsibilities, a firm ethical foundation and normative approval. Mapping the literature has revealed tensions between pragmatic and moral legitimacy, and generated implications for theory on ISR and on legitimacy. Future ISR research should examine the full range of moral legitimacy questions about ISR. Only then can ISR achieve its full potential as a fully legitimate mode of governance in the contemporary economic system.

Acknowledgements The work was funded by the UK's Economic and Social Research Council (ESRC: ES/K007440/1).

\section{Compliance with Ethical Standards}

Conflict of interest The author declares that they have no conflict of interest.

Ethical Approval This article does not contain any studies with human participants or animals performed by any of the authors.

Open Access This article is distributed under the terms of the Creative Commons Attribution 4.0 International License (http://crea tivecommons.org/licenses/by/4.0/), which permits unrestricted use, distribution, and reproduction in any medium, provided you give appropriate credit to the original author(s) and the source, provide a link to the Creative Commons license, and indicate if changes were made. 


\section{References}

Aravind, D., \& Christmann, P. (2011). Decoupling of standard implementation from certification: Does quality of ISO 14001 implementation affect facilities' environmental performance? Business Ethics Quarterly, 21, 73-102.

Banerjee, S. B. (1998). Corporate environmentalism: Perspectives from organizational learning. Management Learning, 29(2), 147-164.

Banerjee, S. B. (2008). Corporate social responsibility: The good, the bad and the ugly. Critical Sociology, 34, 51-79.

Barnett, M. L., \& King, A. A. (2008). Good fences make good neighbors: A longitudinal analysis of an industry self-regulatory institution. Academy of Management Journal, 51, 1150-1170.

Bartley, T. (2003). Certifying forests and factories: States, social movements, and the rise of private regulation in the apparel and forest products fields. Politics and Society, 31, 433-464.

Bartley, T. (2005). Corporate accountability and the privatization of labor standards: struggles over codes of conduct in the apparel industry. Research in Political Sociology, 14, 211-244.

Baur, D., \& Palazzo, G. (2011). The moral legitimacy of NGOs as partners of corporations. Business Ethics Quarterly, 21, 579-604.

Berchicci, L., \& King, A. (2008). Postcards from the edge: A review of the business and environment literature. Academy of Management Annals, 1, 513-547.

Bitektine, A. (2011). Toward a theory of social judgments of organizations: The case of legitimacy, reputation, and status. Academy of Management Review, 36, 151-179.

Black, J. (2008). Constructing and contesting legitimacy and accountability in polycentric regulatory regimes. Regulation and Governance, 2, 137-164.

Blackman, A., \& Rivera, J. (2011). Producer-level benefits of sustainability certification. Consertation Biology, 25, $1176-1185$.

Boiral, O. (2007). Corporate greening through ISO 14001: A rational myth? Organization Science, 18, 127-146.

Boiral, O. (2012). ISO Certificates as organizational degrees? Beyond the rational myths of the certification process. Organization Studies, 33, 633-654.

Boiral, O. (2013). Sustainability reports as simulacra? A counteraccount of A and A + GRI reports. Accounting, Auditing and Accountability Journal, 26, 1036-1071.

Bowen, F. (2014). After greenwasing: Symbolic corporate enviornmentalism and society. Cambridge: Cambridge University Press.

Braithwaite, J. (2008). Regulatory capitalism: How it works, ideas for making it work better. Cheltenham: Edward Elgar.

Bromley, P., \& Powell, W. W. (2012). From smoke and mirrors to walking the talk: Decoupling in the contemporary world. The Academy of Management Annals, 6, 483-530.

Carbon Neutral Company. (2013). The CarbonNeutral Protocol: The global standard for carbon neutral programmes Version 8. London and New York: The Carbon Neutral Company.

Carbon Neutral Company. (2016). CarbonNeutral ${ }^{\circledR}$ Certifications. http://www.carbonneutral.com/our-services/carbonneutral-certifi cations. Accessed 10 March 2016.

Cashore, B. (2002). Legitimacy and the privatization of environmental governance: How non-state market-driven NSMD) governance systems gain rule-making authority. Governance, 15 , 503-529.

Chan, E., Qian, Q. K., \& Lam, P. T. I. (2009). The market for green building in developed Asian cities: The perspectives of building designers. Energy Policy, 37, 3061-3070.

Chao, R. (2013). Dhaka factory collapse: Ho far can businesses be held responsible? The Guardian, 16 May 2013.
Chatterji, A. K., \& Toffel, M. W. (2010). How firms respond to being rated. Strategic Management Journal, 31, 917-945.

Christensen, L. T., Morsing, M., \& Thyssen, O. (2013). CSR as aspirational talk. Organization, 20, 372-393.

Christmann, P., \& Taylor, G. (2006). Firm self-regulation through international certificable standards: Determinants of symbolic versus substantive implementation. Journal of International Business Studies, 37, 863-878.

Coglianese, C., \& Mendelson, E. (2010). Meta-regulation and selfregulation. In R. Baldwin, M. Cave, \& M. Lodge (Eds.), The Oxford handbook of regulation (pp. 146-168). Oxford: Oxford University Press.

Coglianese, C., \& Nash, J. (2001). Regulating from the inside: Can environmental management systems achieve policy goals? Washington, DC: RFF Press.

Conroy, M. E. (2007). Branded! How the 'certification revolution' is transforming global corporations. Gabriola Island, BC: New Society Publishers.

Corbett, C., \& Muthulingam, S. (2007). Adoption of voluntary environmental standards: The role of signaling and intrinsic benefits in the diffusion of the LEED green building standards. Anderson School of Business, UCLA: 32, Los Angeles, CA.

Crane, A. (2000). Corporate greening as amoralization. Organization Studies, 21, 673-696.

Darnall, N., \& Carmin, J. (2005). Greener and cleaner? The signaling accuracy of US voluntary environmental programs. Policy Sciences, 38, 71-90.

Darnall, N., Henriques, I., \& Sadorsky, P. (2009). Adopting proactive environmental practices: The influence of stakeholders and firm size. Journal of Management Studies, 47, 1072-1094.

Darnall, N., \& Sides, S. (2008). Assessing the performance of voluntary environmental programs: Does certification matter? Policy Studies Journal, 36, 95-117.

Dart, R. (2004). The legitimacy of social enterprise. Nonprofit Management and Leadership, 14, 411-424.

Delmas, M. A. (2002). The diffusion of environmental management standards in Europe and in the United States: An institutional perspective. Policy Sciences, 35, 91-119.

Delmas, M., \& Keller, A. (2005). Free riding in voluntary environmental programs: The case of the U.S. EPA WasteWise program. Policy Sciences, 38, 91-106.

Delmas, M., \& Montes-Sancho, M. (2010). Voluntary agreements to improve environmental quality: Symbolic and substantive cooperation. Strategic Management Journal, 31, 575-601.

Delmas, M., \& Montes-Sancho, M. (2011). An institutional perspective on the diffusion of international management system standards: The case of the environmental management standard ISO 14001. Business Ethics Quarterly, 21, 103-132.

Delmas, M. A., \& Terlaak, A. K. (2001). A framework for analyzing environmental voluntary agreements. California Management Review, 43, 44-63.

Delmas, M., \& Toffel, M. W. (2008). Organizational response to environmental demands: Opening the black box. Strategic Management Journal, 29, 1027-1055.

Delmas, M., \& Young, O. (2009). New Perspectives in Governance for Sustainable Development. Cambridge: Cambridge University Press.

Department of Energy and Climate Change. (2009). Guidance on carbon neutrality. London: DECC.

DiMaggio, P. J., \& Powell, W. W. (1983). The iron cage revisited: Institutional isomorphism and collective rationality in organizational fields. American Sociological Review, 48, 147-160.

Dunlap, R. E., \& McCright, A. M. (2011). Organized climate change denial. In J. S. Dryzek, R. B. Norgaard, \& D. Scholsberg (Eds.), The Oxford handbook of climate change and society. Oxford: Oxford University Press. 
Edelman, L. B. (1992). Legal ambiguity and symbolic structures: Organizational mediation of civil rights law. American Journal of Sociology, 97(6), 1531-1576.

Edelman, L., Petterson, S., Chambliss, E., \& Erlanger, H. (1991). Legal ambiguity and the politics of compliance: Affirmative action officers' dilemma. Law and Policy, 13, 73-97.

Elms, H., \& Phillips, R. (2009). Private security companies and institutional legitimacy: Corporate and stakeholder responsibility. Business Ethics Quarterly, 19, 403-432.

Fineman, S., \& Clarke, K. (1996). Green stakeholders: Industry interpretations and response. Journal of Management Studies, 33, 715-730.

Fleckinger, P., \& Glachant, M. (2011). Negotiating a voluntary agreement with firms self-regulate. Journal of Environmental Economics and Management, 62, 41-52.

Freeman, R. (2005). Fighting for other folks' wages: The logic and illogic of living wage campaigns. Industrial Relations: A Journal of Economy and Society, 44, 14-31.

Fuller, T., \& Tian, Y. (2006). Social and symbolic capital and responsible entrepreneurship: An empirical investigation of SME narratives. Journal of Business Ethics, 67, 287-304.

Gamper-Rabindran, S., \& Finger, S. R. (2013). Does self-regulation reduce pollution? Responsible Care in the chemicals industry. Journal of Regulatory Economics, 43, 1-30.

Gereffi, G., Garcia-Johnson, R., \& Sasser, E. (2001). The NGOIndustrial complex. Foreign Policy, 25, 56-65.

Gilbert, D. U., \& Rasche, A. (2007). Discourse ethics and social accountability: The ethics of SA 8000. Business Ethics Quarterly, 17, 187-216.

Green, S. (2004). A rhetorical theory of diffusion. Academy of Management Review, 29, 653-669.

Gross, T. (2013). Rana Plaza: Private governance and corporate power in global supply chains. http://column.global-labouruniversity.org/2013/07/rana-plaza-private-governance-and.html

Gunningham, N. (1995). Environment, self-regulation and the chemical industry: Assessing Responsible Care. Law and Policy, 17, 57-109.

Gunningham, N., \& Rees, J. (1997). Industry self-regulation: An institutional perspective. Law and Policy, 19, 363-414.

Gupta, A. K., \& Lad, L. J. (1983). Industry self-regulation: An economic, organizational and political analysis. Academy of Management Review, 8, 416-425.

Haack, P., Schöneborn, D., \& Wickert, C. (2012). Talking the talk, moral entrapment, creeping commitment? Exploring narrative dynamics in corporate responsibility standardization. Organization Studies, 33, 815-845.

Hahn, T., \& Pinkse, J. (2014). Private environmental governance through cross-sector partnerships: Tensions between competition and effectiveness. Organization and Environment, 27, $140-160$.

Haufler, V. (2001). A public role for the private sector: Industry selfregulation in a global economy. New York: Carnegie Endowment.

Hoffman, A. J. (1999). Institutional evolution and change: Environmentalism and the US chemical industry. Academy of Management Journal, 42, 351-371.

Husted, B. W., Montiel, I., \& Christmann, P. (2016). Effects of local legitimacy on certification decisions to global and national CSR standards by multinational subsidiaries and domestic firms. Journal of International Business Studies, 47, 382-397.

Jahn, G., Schramm, M., \& Spiller, A. (2005). The reliability of certification: Quality labels as a consumer policy tool. Journal of Consumer Policy, 28, 53-73.

Jermier, J., Forbes, L., Benn, S., \& Orsato, R. (2006). The new corporate environmentalism and green politics. In S. R. Clegg, C. Hardy, T. Lawrence, \& W. R. Nord (Eds.), The sage handbook of organization studies (pp. 618-650). Thousand Oaks, CA: Sage.

Jiang, R. J., \& Bansal, P. (2003). Seeing the need for ISO 14001. Journal of Management Studies, 40, 1047-1067.

Kassinis, G., \& Vafeas, N. (2006). Stakeholder pressures and environmental performance. Academy of Management Journal, $49,145-169$.

King, A. A., \& Lenox, M. J. (2000). Industry self-regulation without sancations: The chemical industry's Responsible Care Program. Academy of Management Journal, 43, 698-716.

King, A. A., Lenox, M. J., \& Barnett, M. (2002). Strategic responses to the reputation commons problem. In A. Hoffman \& M. Ventresca (Eds.), Organizations, policy, and the natural environment: Institutional and strategic perspectives (pp. 393-406). Palo Alto: Stanford University Press.

King, A. A., Lenox, M. J., \& Terlaak, A. (2005). The strategic use of decentralized institutions: Exploring certification with the ISO 14001 management standard. Academy of Management Journal, 48, 1091-1106.

King, A., Prado, A., \& Rivera, J. (2012). Industry self-regulation and environmental protection. In P. Bansal \& A. Hoffman (Eds.), The Oxford handbook of business and the natural environment (pp. 103-121). Oxford: Oxford University Press.

King, A., \& Toffel, M. W. (2009). Self-regulatory institutions for solving environmental problems. In M. Delmas \& O. R. Young (Eds.), Governance for the environment: New perspectives (pp. 98-116). Cambridge: Cambridge University Press.

Kolk, A., \& van Tulder, R. (2002). Child labor and multinational conduct: A comparison of international business and stakeholder codes. Journal of Business Ethics, 36, 291-301.

Koppell, J. G. S. (2008). Global governance organizations: Legitimacy and authority in conflict. Journal of Public Administration Research and Theory, 18, 177-203.

Kraatz, M. S. (1998). Learning by association? Interorganizational networks and adaptation to environmental change. Academy of Management Journal, 41, 621-643.

Lee, B. H. (2009). The infrastructure of collective action and policy content diffusion in the organic food industry. Academy of Management Journal, 52, 1247-1269.

Lenox, M. J., \& Nash, J. (2003). Industry self-regulation and adverse selection: a comparison across four trade association programs. Business Strategy and the Environment, 12, 343-356.

Levy, D. L. (2008). Political contestation in global production networks. Academy of Management Review, 33, 943-963.

Levy, D. L., \& Egan, D. (2003). A neo-Gramscian approach to corporate political strategy. Journal of Management Studies, 40, 803-829.

Lin-Hi, N., \& Blumberg, I. (2016). The power(lessness) of industry self-regulation: Insights from the Chinese toy industry. Journal of Business Ethics. doi:10.1007/s10551-016-3075-0.

Locke, R. M. (2013). The promise and limits of private power: Promoting labor standards in a global economy. Cambridge: Cambridge University Press.

Locke, R. M., Qin, F., \& Brause, A. (2007). Does monitoring improve labor standards: Lessons from Nike. Industrial and Labor Relations Review, 61, 3-18.

Locke, R. M., Rissing, B. A., \& Pal, T. (2013). Complements or substitutes? Private codes, state regulation and the enforcement of labour standards in global supply chains. British Journal of Industrial Relations, 51, 519-552.

Long, B. S., \& Driscoll, C. (2008). Codes of ethics and the pursuit of organizational legitimacy: Theoretical and empirical contributions. Journal of Business Ethics, 77, 173-189.

Majumdar, S. K., \& Marcus, A. A. (2001). Rules versus discretion: The productivity consequences of flexible regulation. Academy of Management Journal, 44, 170-179. 
Marquis, C., Glynn, M. A., \& Davis, G. F. (2007). Community isomorphism and corporate social action. Academy of Management Review, 32, 925-945.

Matten, D. (2003). Symbolic politics in environmental regulation: Corporate strategic responses. Business Strategy and the Environment, 12, 215-226.

Matten, D., \& Moon, J. (2008). Implicit and explicit CSR: A conceptual framework for a comparative understanding of corporate social responsibility. Academy of Management Review, 33, 404-424.

Maxwell, J., Lyon, T., \& Hackett, S. (2000). Self-regulation and social welfare: The political economy of corporate environmentalism. Journal of Law and Economics, 43, 583-617.

Meidinger, E. (2006). The administrative law of global private-public regulation: The case of forestry. European Journal of International Law, 17, 47-87.

Melé, D., \& Armengou, J. (2015). Moral legitimacy in controversial projects and its relationship with social licence to operate: A case study. Journal of Business Ethics. doi:10.1007/s1055101502866-z.

Mele, V., \& Schepers, D. H. (2013). E Pluribus Unum? Legitimacy issues and multistakeholder codes of conduct. Journal of Business Ethcs, 118(3), 561-576.

Meyer, J. W., \& Rowan, B. (1977). Institutionalized organizations: Formal structure as myth and ceremony. American Journal of Sociology, 83, 340-363.

Microsoft. (2012). Becoming carbon neutral. Redmond, WA: Microsoft.

Moog, S., Spicer, A., \& Bohm, S. (2015). The politics of multistakeholder initiatives: The crisis of the Forest Stewarship Council. Journal of Business Ethics, 128(3), 469-493.

Moore, S. E., Cubbage, F., \& Eicheldinger, C. (2012). Impacts of Forest Stewardship Council (FSC) and Sustianable Forestry Initiative (SFI) forest certification in North America. Journal of Forestry, 110(2), 79-88.

Ogus, A. (1995). Rethinking self-regulation. Oxford Journal of Legal Studies, 15, 97-108.

Oliver, C. (1991). Strategic responses to institutional processes. Academy of Management Review, 16, 145-179.

O'Rourke, D. (2003). Outsourcing regulation: Analyzing nongovernmental systems of labor standards and monitoring. Policy Studies Journal, 31, 1-29.

Ostrom, E. (1990). Governing the commons: The evolution of institutions for collective action. Cambridge: Cambridge University Press.

Parker, C. (2002). The open corporation: Effective self-regulation and democracy. Cambridge: Cambridge University Press.

Parker, J. (2009). BREEAM or LEED? Strengths and weaknesses of the two main environmental assessment methods. Bracknell: BSRIA.

Pearson, R., \& Seyfang, G. (2001). New hope or false dawn? Voluntary codes of conduct, labor regulation and social policy in a globalizing world. Global Social Policy, 1, 48-78.

Pollin, R., Brenner, M., \& Stephanie, L. (2002). Intended versus unintended consequences: Evaluating the New Orleans living wage ordinance. Journal of Economic Issues, 36, 843-875.

Prado, A. M. (2013). Competition among self-regulatory institutions: Sustainability certifications in the cut-flower industry. Business and Society, 52, 686-707.
Prado, A. M., \& Woodside, A. G. (2015). Deepening understanding of certification adoption and non-adoption of international-supplier ethical standards. Journal of Business Ethics, 132(1), 105-125.

Prakash, A., \& Potoski, M. (2006). The voluntary environmentalists: Green clubs, ISO 14001 and voluntary environmental regulations. Cambridge: Cambridge University Press.

Raynolds, L. T., Murray, D., \& Heller, A. (2007). Regulating sustainability in the coffee sector: A comparative analysis of third party environmental and social certification initiatives. Agriculture and Human Values, 24, 147-163.

Reich, M., Hall, P., \& Jacobs, K. (2005). Living wage policies at the San Francisco airport: Impacts on workers and businesses. Industrial Relations: A Journal of Economy and Society, 44, 106-138.

Reinecke, J., Manning, S., \& Von Hagen, O. (2012). The emergence of a standards market: Multiplicity of sustainability standards in the global coffee industry. Organization Studies, 33, 791-814.

Renard, M.-C. (2005). Quality certification, regulation and power in fair trade. Journal of Rural Studies, 21, 419-431.

Rivera, J. (2002). Assessing a voluntary environmental initiative in the developing world: The Costa Rican certification for sustainable tourism. Policy Sciences, 35, 333-360.

Russo, M., \& Harrison, N. (2005). Organizational design and environmental performance: Clues from the electronics industry. Academy of Management Journal, 48, 582-593.

Schepers, D. H. (2010). Challenges to legitimacy at the Forest Stewardship Council. Journal of Business Ethics, 92, 279-290.

Schuler, D. A., \& Christmann, P. (2011). The effectiveness of marketbased social governance schemes: The case of fair trade coffee. Business Ethics Quarterly, 21, 133-156.

Short, J. L., \& Toffel, M. W. (2010). Making self-regulation more than merely symbolic: The critical role of the legal environment. Administrative Science Quarterly, 55, 361-396.

Suchman, M. C. (1995). Managing legitimacy: Strategic and institutional approaches. Academy of Management Review, 20, 571-610.

Terlaak, A. (2007). Order without law: The role of certified management standards in shaping socially desired firm behaviors. Academy of Management Review, 32, 968-985.

Vogel, D. (2008). Private global business regulation. Annual Review of Political Science, 11, 261-282.

Vogel, D. (2010). The private regulation of global corporate conduct: Achievements and limitations. Business and Society, 49, 68-87.

Wijen, F. (2014). Means versus ends in opaque institutional fields: Trading off compliance and achievement in sustainability standard adoption. Academy of Management Review, 39(3), 302-323.

Wills, J., \& Linneker, B. (2012). The costs and benefits of the London living wage. London: Trust for London/Queen Mary University of London.

Winn, M., MacDonald, P., \& Zietsma, C. (2008). Managing industry reputation: The dynamic tension between collective and competitive reputation. Corporate Reputation Review, 11, 35-55.

Zietsma, C., \& Lawrence, T. B. (2010). Institutional work in the transformation of an organizational field: The interplay of boundary work and practice work. Administrative Science Quarterly, 55, 189-221. 